\title{
ANALISIS TINGKAT KELELAHAN SUBYEKTIF BERDASARKAN SIKAP KERJA PENJAHIT DI INDUSTRI KONVEKSI
}

\author{
ANALYSIS OF SUBJECTIVE FATIGUE RATE BASED ON THE ATTITUDE \\ OF WORKERS IN CONVECTION INDUSTRY
}

\author{
Triana Izzati, Denny Ardyanto W. \\ Departemen Keselamatan dan Kesehatan Kerja \\ Fakultas Kesehatan Masyarakat Universitas Airlangga \\ E-mail: trianaizzati@gmail.com
}

\begin{abstract}
Work manner affects health safety and environment in the work station. It also affects workers' fatigue which can reduce their performance resulting from the excessive of physical and mental at the working environment. The purpose of this study was to analyze the relationship between the tailor work attitude with the incidence of work fatigue on workers in the Ramli convection industry that engaged in fashion. The research was a descriptive by using the assessment of RULA model that targets of body posture of the workers in the Convection Industry. This research aimed to estimate the risk accident of skeletal muscle disorder and to assess work attitude which having pain, fatigue and musculoskeletal disorder by using RULA Model. The improvement of work attitude with changing of work position by standing up and sitting down, not slouching and not bending, and the improvement of work station such as making the ergonomic of the tailors' chair. The results showed a strong correlation between fatigue with age $(r=0.711)$, work period $(r=0.854)$, intermediate relationship with gender $(r=0.439)$, work attitude $(r=0.416)$, and the working environment $(r=0.419)$. The result showed a weak correlation between fatigue with work station $(r=0.448)$. The conclusion is workers who have a high risk of work attitude experience a higher level of fatigue.
\end{abstract}

Keywords: work attitude, work fatigue, work station

\begin{abstract}
ABSTRAK
Cara kerja sangat mempengaruhi tercapainya keselamatan dan kesehatan dalam bekerja. Kelelahan kerja dapat menurunkan performa akibat dari penggunaan berlebih pada fisik dan mental. Tujuan dari penelitian ini adalah menganalisis tingkat kelelahan kerja yang dialami penjahit berdasarkan sikap kerja. Penelitian berfokus pada industri konveksi x dengan analisis deskriptif melalui penilaian metode RULA, yaitu metode dengan menggunakan target postur tubuh untuk mengestimasi terjadinya risiko gangguan otot skeletal dan digunakan untuk menilai sikap kerja yang mengalami keluhan kelelahan. Hasil dari grand score penilaian sikap kerja yang menggunakan metode RULA menunjukkan bahwa perlu dilakukan penyelidikan dan perbaikan segera. Perbaikan sikap kerja dapat dilakukan dengan perubahan posisi kerja dengan berdiri dan duduk, sikap kerja tidak membungkuk, serta perbaikan stasiun kerja seperti bentuk kursi penjahit yang ergonomis. Hasil penelitian menunjukkan sebagian besar mengalami kelelahan tingkat tinggi, dan berdasarkan hasil tabulasi silang didapatkan hubungan kuat antara kelelahan dengan usia $(\mathrm{r}=0,711)$, masa kerja $(\mathrm{r}=0,854)$, tingkat hubungan sedang antara jenis kelamin $(\mathrm{r}=0,439)$, sikap kerja $(\mathrm{r}=0,416)$, dan lingkungan kerja $(\mathrm{r}=0,419)$. Hubungan rendah antara kelelahan dengan stasiun kerja $(\mathrm{r}=0,226)$. Kesimpulannya adalah pekerja yang memiliki risiko sikap kerja tinggi mengalami tingkat kelelahan yang semakin tinggi.
\end{abstract}

Kata kunci: kelelahan kerja, sikap kerja, stasiun kerja

\section{PENDAHULUAN}

Persaingan industri yang semakin ketat menuntut perusahaan untuk mengoptimalkan seluruh sumber daya yang dimiliki dalam menghasilkan produk berkualitas tinggi agar mampu bertahan dalam persaingan dengan perusahaan lain (Sinyo, 2015).
Setiap pekerjaan memiliki risiko menyebabkan kelelahan, yang dikenal dengan kelelahan kerja. Kelelahan kerja dapat mengakibatkan prestasi kerja menurun, badan tidak enak, serta menurunnya semangat kerja hingga berpengaruh pada produktivitas (Fitrihana, 2008). Kelelahan kerja 
akan menurunkan kinerja dan menambah tingkat kesalahan kerja. Meningkatnya kesalahan kerja akan memberikan peluang terjadinya kecelakaan kerja dalam industri (Nurmianto, 2003). Kelelahan juga berpotensi untuk mengakibatkan kecelakaan kerja

Kesehatan dan keselamatan kerja (K3) adalah kondisi atau faktor yang mempengaruhi atau dapat mempengaruhi kesehatan dan keselamatan pekerja atau pekerja lain (termasuk pekerja sementara dan kontraktor), pengunjung, atau setiap orang di tempat kerja (Ramli, 2013). Menurut Tarwaka (2015) kelelahan yang disebabkan karena kerja statis akan berbeda dengan kerja dinamis. Pada otot statis, dengan pengerahan tenaga $50 \%$ dari kekuatan maksimum otot hanya dapat bekerja selama 1 menit, sedangkan pada pengerahan tenaga $<20 \%$ kerja fisik dapat berlangsung lebih lama. Pengerahan tenaga otot statis sebesar 15-20\% akan menyebabkan kelelahan dan nyeri jika pembebanan berlangsung sepanjang hari.

Beberapa penelitian yang menunjukkan bahwa faktor individu dalam hal ini seperti umur, pendidikan, masa kerja, status perkawinan, dan status gizi mempunyai hubungan terhadap terjadinya kelelahan kerja (Oentoro, 2004). Keselamatan dan Kesehatan Kerja merupakan salah satu faktor penting dalam kelancaran produksi sehingga program K3 harus diterapkan di perusahaan dan bukan hanya sekedar wacana. Kecelakaan kerja merupakan kecelakaan yang terjadi dalam lingkungan kerja yang dapat terjadi karena kondisi lingkungan kerja yang tidak aman atau human error (Restuputri, 2015).

Penelitian ini akan mengambil subjek penelitian kelelahan subjektif pada penjahit di Industri konveksi $\mathrm{x}$ Gresik. Industri konveksi X merupakan salah satu home industry baju busana muslim yang terdapat di daerah Gresik. Industri baju ini terletak di pusat kota Gresik dan berdekatan dengan pasar Gresik. Pekerja di industri konveksi X bekerja selama 8 jam, istirahat 1 jam dan 6 hari selama seminggu. Proses produksi baju, industri konveksi X memerlukan peran manusia terutama dalam segi fisik.

Faktor pekerjaan yang dapat yang dapat menyebabkan kelelahan pada penjahit adalah pekerjaan yang monoton, postur duduk yang cenderung membungkuk ke arah mesin jahit/ postur janggal dan kebutuhan visual. Faktor risiko tersebut disebabkan oleh postur pekerjaanya sendiri, pergerakan yang berulang sebagai tuntutan dari pekerjaan dan desain tempat duduk yang tidak memadai, tinggi meja yang tidak sesuai, kurangnya pencahayaan, penempatan pedal yang membuat postur kaki dan lutut menjadi salah, dan ukuran mesin yang tidak sesuai (Kaergaard \& Andersen, 2000). Metode RULA merupakan suatu metode dengan menggunakan target postur tubuh untuk mengestimasi terjadinya risiko gangguan otot skeletal, khususnya pada anggota tubuh bagian atas (upper limb disorders). Penerapan dari metode ini dapat meningkatkan kenyamanan kerja, sebagai peningkatan kualitas produksi, setelah dilakukannya perbaikan sikap kerja (Tarwaka, 2010).

Penelitian ini dilakukan pengamatan dan penelitian terhadap Faktor pekerjaan (sikap kerja, stasiun kerja) dan factor lingkungan (suhu, cahaya, kebisingan) menyebabkan karakteristik pekerja mengalami kejadian kelelahan kerja serta pengukuran kelelahan secara subjektif. Menyikapi hal tersebut, mengacu pada peraturan K3, maka semua pihak yang terkait dengan proses produksi untuk meningkatkan kesadaran dalam melaksanakan keselamatan dan kesehatan kerja di setiap tempat kerja dan program membudayakan keselamatan dan kesehatan kerja menjadi tanggung jawab semua pihak yang terkait dengan proses produksi (Lettyzia, 2015).

\section{METODE}

Berdasarkan cara pengumpulan data, penelitian ini termasuk penelitian observasional, sementara itu berdasarkan sistem analisisnya, termasuk penelitian deskriptif dan ditinjau dari waktunya, penelitian ini bersifat cross sectional karena mempelajari dinamika korelasi antara faktor risiko dengan efek, dengan cara pendekatan, observasi, atau pengumpulan data sekaligus pada suatu saat (Notoatmodjo, 2002).

Populasi dalam penelitian ini merupakan seluruh pekerja penjahit di industry konveksi X Gresik berjumlah 20 pekerja. Pengolahan data dengan menggunakan tabulasi silang dan uji spearman untuk melihat kekuatan hubungan antar variabel, tanpa melakukan uji signifikansi. Korelasi spearman merupakan suatu pengujian yang berfungsi untuk mencari tahu kedekatan hubungan antar variabel. Hasil dari uji korelasi ini bernilai antara +1 hingga -1 .

Penilaian postur tubuh peneliti menggunakan metode RULA yang merupakan suatu metode dengan menggunakan target postur tubuh untuk mengestimasi terjadinya risiko gangguan otot skeletal, khususnya pada anggota tubuh bagian atas (upper limb disorders), seperti; adanya gerakan 
repetitif, pekerjaan diperlukan kekuatan, aktivitas otot statis pada otot skeletal, dan lain-lain.

Penilaian dengan metode RULA ini merupakan penilaian yang sistematis dan cepat terhadap risiko terjadinya gangguan dengan menunjuk bagian anggota tubuh pekerja yang mengalami gangguan tersebut. Analisis dapat dilakukan sebelum dan sesudah intervensi, untuk menunjukkan bahwa intervensi yang diberikan akan dapat menurunkan risiko cedera. Metode ini menggunakan diagram dari postur tubuh dan tiga tabel skor dalam menetapkan evaluasi faktor risiko. Faktor risiko yang telah diinvestigasi dijelaskan oleh McPhee sebagai faktor beban eksternal yaitu 1) Jumlah pergerakan; 2) Kerja otot statis; 3) Tenaga/kekuatan; 4) Penentuan postur kerja oleh peralatan; dan 5) Waktu kerja tanpa istirahat.

\section{HASIL}

Hasil deskripsi awal perusahaan menunjukkan bahwa Industri konveksi Ramli merupakan sebuah industri kecil menengah yang menghasilkan barang hasil konveksi berupa busana muslim laki-laki berlokasi di Jalan Sindujoyo XVII No. 1 Gresik, Provinsi Jawa Timur.

Identifikasi sikap kerja yang dapat menimbulkan kelelahan yang dilakukan pada responden yaitu penjahit yang bekerja di industri konveksi $\mathrm{x}$ dimana pekerjaanya meliputi pemotongan kain, menjahit, menyetrika, dan finishing melalui dokumentasi, selanjutnya hasil dokumentasi berupa foto tersebut diidentifikasi dengan cara menghitung sudut anggota tubuh responden menggunakan busur penggaris.

Tabel 1. Tabel Standar Kinerja Berdasarkan Skor Akhir RULA

\begin{tabular}{ccl}
\hline $\begin{array}{c}\text { Skor } \\
\text { Akhir }\end{array}$ & Level & \multicolumn{1}{c}{ Tindakan } \\
\hline $1-2$ & 1 & $\begin{array}{l}\text { Tidak ada masalah dengan postur } \\
\text { tubuh selama kerja }\end{array}$ \\
$3-4$ & 2 & $\begin{array}{l}\text { Diperlukan investigasi lebih } \\
\text { lanjut, mungkin diperlukan } \\
\text { adanya perubahan untuk } \\
\text { perbaikan sikap kerja }\end{array}$ \\
$5-6$ & 3 & $\begin{array}{l}\text { Diperlukan adanya investigasi dan } \\
\text { perbaikan segera } \\
\text { Diperlukan adanya investigasi dan } \\
\text { perbaikan secepat mungkin }\end{array}$ \\
\hline $7+$ & 4 & \\
\hline
\end{tabular}

Setelah mendapatkan hasil besar sudut kemudian dilakukan scoring pada masing-masing tubuh yang kemudian disesuaikan dengan tabel scoring RULA.

Hasil dari pengukuran sudut lengan atas pada seluruh responden yang disesuaikan dengan tabel scoring RULA menunjukkan bahwa sebagian besar penjahit yaitu sejumlah $60 \%$ bekerja dalam posisi lengan atas membentuk sudut fleksi $45^{\circ}-90^{\circ}$. Sebagian besar penjahit yaitu sejumlah $70 \%$ bekerja dalam posisi lengan bawah membentuk sudut fleksi $<60^{\circ}$ atau $>100^{\circ}$ dan sejumlah $55 \%$ bekerja dalam posisi pergelangan tangan membentuk sudut fleksi $>15^{\circ}$.

Selain itu, hasil dari pengukuran sudut leher pada seluruh responden yang disesuaikan dengan tabel scoring RULA menunjukkan bahwa sebagian besar penjahit yaitu sejumlah $55 \%$ bekerja dalam posisi leher membentuk sudut fleksi $>20^{\circ}$. Hasil dari pengukuran sudut badan pada seluruh responden yang disesuaikan dengan tabel scoring RULA menunjukkan bahwa sebagian besar penjahit yaitu sejumlah $40 \%$ bekerja dalam posisi leher membentuk sudut fleksi $20-60^{\circ}$. Selain itu juga menunjukkan bahwa sebagian besar penjahit yaitu $80 \%$ bekerja

Tabel 2. Distribusi Skor C metode RULA

\begin{tabular}{cccc}
\hline Responden & $\begin{array}{c}\text { Skor Awal } \\
\text { Grup A }\end{array}$ & $\begin{array}{c}\text { Skor Keadaan } \\
\text { Statis }\end{array}$ & Skor C \\
\hline 1 & 4 & 1 & 5 \\
2 & 4 & 1 & 5 \\
3 & 3 & 1 & 4 \\
4 & 4 & 1 & 5 \\
5 & 4 & 1 & 5 \\
6 & 4 & 1 & 5 \\
7 & 5 & 1 & 6 \\
8 & 4 & 1 & 5 \\
9 & 5 & 1 & 6 \\
10 & 4 & 1 & 5 \\
11 & 4 & 1 & 5 \\
12 & 3 & 1 & 4 \\
13 & 4 & 1 & 5 \\
14 & 5 & 1 & 6 \\
15 & 4 & 1 & 5 \\
16 & 5 & 1 & 6 \\
17 & 4 & 1 & 5 \\
18 & 4 & 1 & 5 \\
19 & 5 & & 6 \\
20 & 5 & 1 & \\
\hline & & 1 & 5 \\
\hline
\end{tabular}


dalam posisi kaki tertopang dengan baik pada saat duduk.

Pada penilaian grup, maka pada scoring untuk penggunaan otot dan pembebanan atau pengerahan tenaga merupakan skor yang diperoleh dari tabel A kemudian ditambah skor 1 , jika sikap tubuh pada saat bekerja dalam keadaan statis untuk waktu lebih dari 1 menit atau dilakukan secara repetitif untuk lebih dari 4 kali per menit sehingga menghasilkan perhitungan untuk skor $\mathrm{C}$ pada Tabel 2 .

Pada scoring untuk penggunaan otot dan pembebanan atau pengerahan tenaga merupakan skor yang diperoleh dari tabel B kemudian ditambah skor 1, jika sikap tubuh pada saat bekerja dalam keadaan statis untuk waktu lebih dari 1 menit atau dilakukan secara repetitif untuk lebih dari 4 kali per menit sehingga menghasilkan perhitungan untuk skor D terdapat pada Tabel 3.

Perhitungan grand skor didapat dari hasil perhitungan skor $\mathrm{C}$ dan $\mathrm{D}$, kemudian digabungkan dalam suatu grand akumulasi skor tunggal antara 1 sampai 7 yang nantinya digunakan sebagai dasar estimasi terhadap risiko pembebanan pada otot skeletal. Grand skor dapat dihitung berdasarkan tabel yang disesuaikan dengan metode RULA ditunjukkan pada Tabel 4.

Tabel 3. Distribusi Skor D metode RULA

\begin{tabular}{|c|c|c|c|}
\hline Responden & $\begin{array}{c}\text { Skor Awal } \\
\text { Grup B }\end{array}$ & $\begin{array}{c}\text { Skor } \\
\text { Keadaan } \\
\text { Statis } \\
\end{array}$ & Skor D \\
\hline 1 & 3 & 1 & 4 \\
\hline 2 & 3 & 1 & 4 \\
\hline 3 & 3 & 1 & 4 \\
\hline 4 & 3 & 1 & 4 \\
\hline 5 & 4 & 1 & 5 \\
\hline 6 & 2 & 1 & 3 \\
\hline 7 & 3 & 1 & 4 \\
\hline 8 & 3 & 1 & 4 \\
\hline 9 & 4 & 1 & 5 \\
\hline 10 & 4 & 1 & 5 \\
\hline 11 & 3 & 1 & 4 \\
\hline 12 & 5 & 1 & 6 \\
\hline 13 & 3 & 1 & 4 \\
\hline 14 & 3 & 1 & 4 \\
\hline 15 & 3 & 1 & 4 \\
\hline 16 & 3 & 1 & 4 \\
\hline 17 & 5 & 1 & 6 \\
\hline 18 & 4 & 1 & 5 \\
\hline 19 & 5 & 1 & 6 \\
\hline 20 & 4 & 1 & 5 \\
\hline
\end{tabular}

Tabel 4. Distribusi Grand Score metode RULA

\begin{tabular}{cccc}
\hline Responden & Skor C & Skor D & Grand Skor \\
\hline 1 & 5 & 4 & 5 \\
2 & 5 & 4 & 5 \\
3 & 4 & 4 & 4 \\
4 & 5 & 4 & 5 \\
5 & 5 & 5 & 6 \\
6 & 5 & 3 & 4 \\
7 & 6 & 4 & 6 \\
8 & 5 & 4 & 5 \\
9 & 6 & 5 & 6 \\
10 & 5 & 5 & 6 \\
11 & 5 & 4 & 5 \\
12 & 4 & 6 & 6 \\
13 & 5 & 4 & 5 \\
14 & 6 & 4 & 6 \\
15 & 5 & 4 & 5 \\
16 & 6 & 4 & 6 \\
17 & 5 & 6 & 7 \\
18 & 5 & 5 & 6 \\
19 & 6 & 6 & 7 \\
20 & 6 & 5 & 5 \\
\hline
\end{tabular}

Hasil dari perhitungan grand skor pada seluruh responden yang disesuaikan dengan tabel scoring

RULA menunjukkan bahwa sebagian besar penjahit yaitu sejumlah 16 orang mendapatkan skor 5 dan 6 sehingga sikap kerja penjahit termasuk dalam level 3. Hasil penilaian sikap kerja penjahit dapat disimpulkan bahwa sebagian besar sikap kerja penjahit termasuk dalam kategori tinggi sebanyak 16 responden $(80 \%)$, sangat tinggi sebanyak 2 responden $(10 \%)$, dan 2 responden $(10 \%)$ memiliki sikap kerja kategori sedang.

Keadaan stasiun kerja dikategorikan menjadi pekerja duduk diatas kursi sebanyak 55\% dan menggunakan meja selama melakukan pekerjaanya dan kategori selanjutnya adalah pekerja duduk langsung diatas lantai selama melakukan pekerjaanya sebanyak 45\%. Keadaan lingkungan kerja diukur menggunakan kuesioner yang meliputi keadaan penerangan, kebisingan, dan suhu lingkungan kerja, menghasilkan data berupa sebanyak $60 \%$ merasa nyaman terhadap kondisi lingkungan kerja, sedangkan 40\% lainnya menyatakan kurang nyaman terhadap kondisi lingkungan kerja. Keluhan lingkungan kerja pada pekerja yang merasa kurang 
Tabel 5. Distribusi Kelelahan di Industri Konveksi X Tahun 2017

\begin{tabular}{lcc}
\hline \multicolumn{1}{c}{ Kategori } & Jumlah (Orang) & Persentase (\%) \\
\hline Rendah & 1 & 5 \\
Sedang & 9 & 45 \\
Tinggi & 10 & 50 \\
\hline Total & 20 & 100 \\
\hline
\end{tabular}

Tabel 6. Hubungan antara Jenis Kelamin dengan Kelelahan di Industri Konveksi X Tahun 2017

\begin{tabular}{lcccccc}
\hline \multirow{2}{*}{$\begin{array}{c}\text { Jenis } \\
\text { Kelamin }\end{array}$} & \multicolumn{4}{c}{ Kejadian Kelelahan } \\
\cline { 2 - 7 } & \multicolumn{2}{c}{ Rendah } & \multicolumn{2}{c}{ Sedang } & \multicolumn{2}{c}{ Tinggi } \\
\cline { 2 - 7 } & $\mathbf{n}$ & $\mathbf{\%}$ & $\mathbf{n}$ & $\mathbf{\%}$ & $\mathbf{n}$ & $\mathbf{\%}$ \\
\hline Laki-laki & 1 & 12,5 & 5 & 62,5 & 2 & 25,0 \\
Perempuan & 0 & 0 & 4 & 33,3 & 8 & 66,7 \\
\hline
\end{tabular}

nyaman yang paling dominan adalah kebisingan yang ditimbulkan oleh mesin jahit di tempat kerja.

Kelelahan kerja diukur menggunakan kuesioner Subjective Self Rating Test (SRRT) dari Industrial Fatigue Research Committee (IFRC) sebagai indikator kelelahan kerja. Hasil penelitian tentang gambaran kelelahan kerja berdasarkan kuesioner Subjective Self Rating Test pada pekerja di Industri konveksi X dapat dilihat pada Tabel 5.

Kelelahan kerja terbanyak 50\% termasuk dalam kategori tinggi, tanda atau gejala yang dirasakan oleh pekerja yang paling dominan adalah kelelahan fisik dengan keluhan antara lain: merasa pening, merasa lelah seluruh badan, rasa ingin berbaring, merasa kaku di bagian bahu dan punggung.

RULA menunjukkan bahwa sebagian besar penjahit yaitu sejumlah 16 orang mendapatkan skor 5 dan 6 sehingga sikap kerja penjahit termasuk dalam level 3. Hasil penilaian sikap kerja penjahit dapat disimpulkan bahwa sebagian besar sikap kerja penjahit termasuk dalam kategori tinggi sebanyak 16 responden $(80 \%)$, sangat tinggi sebanyak 2 responden (10\%), dan 2 responden (10\%) memiliki sikap kerja kategori sedang.

Keadaan stasiun kerja dikategorikan menjadi pekerja duduk diatas kursi sebanyak 55\% dan menggunakan meja selama melakukan pekerjaanya dan kategori selanjutnya adalah pekerja duduk langsung diatas lantai selama melakukan pekerjaanya sebanyak 45\%. Keadaan lingkungan kerja diukur menggunakan kuesioner yang meliputi keadaan
Tabel 7. Hubungan antara Usia dengan Kelelahan di Industri Konveksi X Tahun 2017

\begin{tabular}{lcccccc}
\hline \multirow{2}{*}{$\begin{array}{l}\text { Masa } \\
\text { Kerja }\end{array}$} & \multicolumn{6}{c}{ Kejadian Kelelahan } \\
\cline { 2 - 7 } & \multicolumn{2}{c}{ Rendah } & \multicolumn{2}{c}{ Sedang } & \multicolumn{2}{c}{ Tinggi } \\
\hline $\begin{array}{l}18-24 \\
\text { tahun }\end{array}$ & 0 & 0 & 3 & 100,0 & 0 & 0 \\
$\begin{array}{l}25-31 \\
\text { tahun }\end{array}$ & 0 & 0 & 4 & 100,0 & 0 & 0 \\
$\begin{array}{l}32-38 \\
\text { tahun }\end{array}$ & 1 & 33,3 & 1 & 33,3 & 1 & 33,3 \\
$\begin{array}{l}39-45 \\
\text { tahun }\end{array}$ & 0 & 0 & 1 & 20,0 & 4 & 80,0 \\
$\begin{array}{l}46-52 \\
\text { tahun }\end{array}$ & 0 & 0 & 0 & 0 & 5 & 100,0 \\
\hline
\end{tabular}

Tabel 8. Hubungan antara Masa Kerja dengan Kelelahan Tahun 2017

\begin{tabular}{|c|c|c|c|c|c|c|}
\hline \multirow{3}{*}{$\begin{array}{l}\text { Masa } \\
\text { Kerja }\end{array}$} & \multicolumn{6}{|c|}{ Kejadian Kelelahan } \\
\hline & \multicolumn{2}{|c|}{ Rendah } & \multicolumn{2}{|c|}{ Sedang } & \multicolumn{2}{|c|}{ Tinggi } \\
\hline & n & $\%$ & n & $\%$ & $\mathbf{n}$ & $\%$ \\
\hline $\begin{array}{l}1-5 \\
\text { tahun }\end{array}$ & 0 & 0,0 & 4 & 100,0 & 0 & 0,0 \\
\hline $\begin{array}{l}6-10 \\
\text { tahun }\end{array}$ & 1 & 16,7 & 5 & 83,3 & 0 & 0,0 \\
\hline $\begin{array}{l}11-15 \\
\text { tahun }\end{array}$ & 0 & 0,0 & 0 & 0,0 & 5 & 100,0 \\
\hline $\begin{array}{l}16-20 \\
\text { tahun }\end{array}$ & 0 & 0,0 & 0 & 0,0 & 3 & 100,0 \\
\hline $\begin{array}{l}21-25 \\
\text { tahun }\end{array}$ & 0 & 0,0 & 0 & 0,0 & 2 & 100,0 \\
\hline
\end{tabular}

penerangan, kebisingan, dan suhu lingkungan kerja, menghasilkan data berupa sebanyak $60 \%$ merasa nyaman terhadap kondisi lingkungan kerja, sedangkan 40\% lainnya menyatakan kurang nyaman terhadap kondisi lingkungan kerja. Keluhan lingkungan kerja pada pekerja yang merasa kurang nyaman yang paling dominan adalah kebisingan yang ditimbulkan oleh mesin jahit di tempat kerja.

Kelelahan kerja diukur menggunakan kuesioner Subjective Self Rating Test (SRRT) dari Industrial Fatigue Research Committee (IFRC) sebagai indikator kelelahan kerja. Hasil penelitian tentang gambaran kelelahan kerja berdasarkan kuesioner Subjective Self Rating Test pada pekerja di Industri konveksi X dapat dilihat pada Tabel 5. 
Kelelahan kerja terbanyak 50\% termasuk dalam kategori tinggi, tanda atau gejala yang dirasakan oleh pekerja yang paling dominan adalah kelelahan fisik dengan keluhan antara lain: merasa pening, merasa lelah seluruh badan, rasa ingin berbaring, merasa kaku di bagian bahu dan punggung.

Pekerja yang paling banyak mengalami tingkat kelelahan tinggi adalah pekerja dengan jenis kelamin perempuan sebanyak $66,7 \%$. Kuat hubungan antara jenis kelamin dengan kejadian kelelahan kerja, diperoleh nilai korelasi r 0,439 yang berarti hubungan antara jenis kelamin terhadap kelelahan kerja dikategorikan sedang.

Dari data pada Tabel 7, menunjukkan bahwa pekerja yang paling banyak mengalami tingkat kelelahan tinggi adalah pekerja pada kategori usia berusia 46-52 tahun. Hasil tersebut dapat disimpulkan bahwa pekerja yang mengalami kelelahan tinggi adalah pekerja yang berusia terlalu tua. Kuat hubungan antara usia dengan kejadian kelelahan kerja, diperoleh korelasi r 0,711 yang berarti hubungan antara usia terhadap kelelahan kerja dikategorikan kuat.

Tabel 9. Hubungan antara Sikap Kerja dengan Kelelahan di Industri Konveksi X Tahun 2017

\begin{tabular}{lcccccc}
\hline \multirow{2}{*}{$\begin{array}{c}\text { Risiko Sikap } \\
\text { Kerja }\end{array}$} & \multicolumn{6}{c}{ Kejadian Kelelahan } \\
\cline { 2 - 7 } & \multicolumn{2}{c}{ Rendah } & \multicolumn{2}{c}{ Sedang } & \multicolumn{2}{c}{ Tinggi } \\
\cline { 2 - 7 } & $\mathbf{n}$ & $\%$ & n & $\%$ & n & $\%$ \\
\hline Sedang & 0 & 0,0 & 2 & 100,0 & 0 & 0,0 \\
Tinggi & 1 & $6,3 \%$ & 7 & 43,8 & 8 & 50,0 \\
Sangat tinggi & 0 & 00,0 & 0 & 0,0 & 2 & 100,0 \\
\hline
\end{tabular}

Pekerja yang paling banyak mengalami tingkat kelelahan tinggi adalah pekerja yang memiliki masa kerja dalam kategori 11-15 tahun. Kuat hubungan antara masa kerja dengan kejadian kelelahan kerja, diperoleh korelasi r 0,854 yang berarti hubungan antara masa kerja terhadap kelelahan kerja dikategorikan kuat.

Pekerja yang memiliki sikap kerja dalam kategori tinggi sebanyak 8 orang mengalami kelelahan kerja tinggi. Kuat hubungan antara sikap kerja dengan kejadian kelelahan kerja, diperoleh korelasi $\mathrm{r}$ 0,416 yang berarti hubungan antara sikap kerja terhadap kelelahan kerja dikategorikan sedang.
Tabel 10.Hubungan antara Stasiun Kerja dengan Kelelahan di Industri Konveksi X Tahun 2017

\begin{tabular}{|c|c|c|c|c|c|c|}
\hline \multirow{3}{*}{ Stasiun Kerja } & \multicolumn{6}{|c|}{ Kejadian Kelelahan } \\
\hline & \multicolumn{2}{|c|}{ Rendah } & \multicolumn{2}{|c|}{ Sedang } & \multicolumn{2}{|c|}{ Tinggi } \\
\hline & n & $\%$ & $\mathbf{n}$ & $\%$ & $\mathbf{n}$ & $\%$ \\
\hline $\begin{array}{l}\text { Dilengkapi } \\
\text { dengan Meja dan } \\
\text { Kursi Kerja }\end{array}$ & 0 & 0,0 & 7 & 63,6 & 4 & 36,4 \\
\hline $\begin{array}{l}\text { Tidak Dilengkapi } \\
\text { Meja dan Kursi } \\
\text { Kerja }\end{array}$ & 1 & 11,1 & 2 & 22,2 & 6 & 66,7 \\
\hline
\end{tabular}

Tabel 11.Hubungan antara Lingkungan Kerja dengan Kelelahan di Industri Konveksi X Tahun 2017

\begin{tabular}{ccccccc}
\hline \multirow{2}{*}{$\begin{array}{c}\text { Lingkungan } \\
\text { Kerja }\end{array}$} & \multicolumn{6}{c}{ Kejadian Kelelahan } \\
\cline { 2 - 7 } & \multicolumn{2}{c}{ Rendah } & \multicolumn{2}{c}{ Sedang } & \multicolumn{2}{c}{ Tinggi } \\
\cline { 2 - 7 } & $\mathbf{n}$ & $\mathbf{\%}$ & $\mathbf{n}$ & $\mathbf{\%}$ & $\mathbf{n}$ & $\mathbf{\%}$ \\
\hline Nyaman & 1 & 8,3 & 7 & 58,3 & 4 & 33,3 \\
Kurang Nyaman & 0 & 0,0 & 2 & 25,0 & 6 & 75,0 \\
\hline
\end{tabular}

Pekerja yang menggunakan meja dan kursi kerja mengalami tingkat kelelahan kerja sedang, yaitu sebanyak 7 orang. Kuat hubungan antara stasiun kerja dengan kejadian kelelahan kerja didapatkan korelasi $r=0,226$ yang berarti terdapat hubungan rendah.

Pekerja yang paling banyak mengalami tingkat kelelahan sedang adalah pekerja yang merasa lingkungan kerjanya nyaman yaitu sebanyak 7 orang. Hasil analisis statistik, untuk mengetahui kuat hubungan antara lingkungan kerja dengan kejadian kelelahan kerja, didapatkan nilai korelasi $r=0,419$. Terdapat korelasi sedang antara persepsi lingkungan kerja dengan kejadian kelelahan.

Hasil uji statistik diketahui variabel yang memiliki hubungan kuat dengan kejadian kelelahan kerja pada pekerja industri konveksi $\mathrm{x}$ adalah usia dan masa kerja, variabel yang memiliki kuat hubungan sedang adalah sikap kerja, dan jenis kelamin, dan variabel yang memiliki hubungan rendah adalah stasiun kerja.

\section{PEMBAHASAN}

Berdasarkan hasil penelitian menunjukkan bahwa usia dan masa kerja memiliki tingkat 
hubungan yang kuat. Hal tersebut sesuai teori bahwa semakin tinggi usia dapat mempengaruhi kekuatan fisik pekerja, selain itu penglihatan, kecepatan membedakan sesuatu, dan membuat keputusan akan semakin menurun.

Kinerja fisik seseorang mencapai puncak dalam usia pertengahan dua puluhan dan kemudian menurun dalam bertambahnya usia. Menurut Tarwaka, dkk. (2004) pekerja mengalami penurunan fisik pada saat umur mencapai 30 tahun ke atas. Setyawati (2010) berpendapat bahwa puncak kekuatan otot pada laki-laki dan wanita sekitar 25-30 tahun. Penurunan kemampuan fisik ini dapat ditandai dengan pekerjaan yang cenderung lambat, perasaan berat di kepala, sering menguap dan mengantuk saat bekerja, akibatnya pekerja lebih cepat mengalami kelelahan. Sehingga responden berpotensi mengalami tingkat kelelahan kerja yang tinggi karena hasil yang didapat sebagian besar responden berusia lebih dari 30 tahun.

Masa kerja akan memberikan pengaruh positif bila semakin lama sesorang bekerja maka akan berpengalaman dalam melakukan pekerjaanya. Sebaliknya masa kerja dapat berpengaruh negatif apabila semakin lama bekerja dapat menimbulkan kelelahan dan kebosanan (Maurits, 2010).

Analisis sikap kerja diperoleh menggunakan metode RULA yaitu penilaian postur, gaya dan gerakan suatu aktivitas kerja yang berkaitan dengan tubuh bagian atas (upper limb), metode ini mentransfer hasil analisis dalam bentuk scoring. Skor final yang diperoleh akan digunakan sebagai pertimbangan untuk melakukan perbaikan. Langkah dalam melakukan metode RULA menurut Tarwaka (2010) yaitu dimulai dengan observasi kegiatan pekerja. Hasil dari observasi akan dipilih manakah pekerjaan yang paling signifikan.

Hasil penelitian menunjukkan bahwa terdapat responden yang melakukan pekerjaan dalam posisi berdiri dan ada dalam posisi duduk. Terdapat 4 pekerja yang melakukan pekerjaan pada posisi berdiri dan 16 pekerja pada posisi duduk. Sikap kerja duduk penjahit terbagi menjadi dua yaitu duduk diatas kursi dan duduk langsung diatas lantai.

Sikap kerja yang dilakukan responden (penjahit) cenderung dilakukan dengan tidak ergonomis karena posisi tubuh penjahit terlalu membungkuk, leher yang terlalu menunduk, posisi lengan yang menyilang, dan pergelangan tangan memuntir. Pekerja pada saat posisi duduk masih terdapat gerakan tidak alamiah dikarenakan badan membungkuk dan memutar ke samping saat mengambil baju yang akan dijahit.
Selain posisi duduk, posisi berdiri yang statis untuk jangka waktu yang cukup lama dapat menyebabkan kelelahan. Halim dan Omar (2011) menyebutkan bahwa posisi berdiri yang lama akan meningkatkan ketidaknyamanan dan kelelahan pada seluruh bagian tubuh. Kondisi ini akan menurunkan sirkulasi darah yang menuju ke bagian bawah tubuh, terutama kaki. Penilaian sikap kerja penjahit disimpulkan bahwa terdapat perbedaan tingkat kelelahan dengan sikap kerja. Sebagian besar sikap kerja penjahit termasuk dalam kategori tinggi. sehingga diperlukannya penyelidikan dan perbaikan segera.

Sebagian besar stasiun kerja responden menggunakan meja dan kursi saat bekerja. Jenis kursi yang dipakai saat duduk yaitu kursi yang tidak dapat diatur ketinggiannya, tidak mempunyai sandaran, dan tinggi kursi tidak dapat diatur secara manual.

Kelelahan pada sikap duduk biasanya disebabkan karena tidak adanya sandaran punggung. Kebiasaan pekerja di industri konveksi X bekerja dengan posisi punggung membungkuk tidak tegap yang dapat menimbulkan otot tulang belakang melengkung sehingga cepat lelah. Hal ini masih kurang memenuhi standar, karena dengan kondisi seperti itu pekerja kurang dapat mempertahankan kondisi tubuh yang alami sehingga kelelahan tidak dapat dihindari. Melihat kondisi tersebut penjahit yang bekerja dalam keadaan statis dan banyak pekerjaan yang dilakukan dalam kondisi tidak alamiah sehingga memicu ketegangan otot, dimana otot ini memicu penimbunan asam laktat pada otot dan pembuluh darah yang dapat menyebabkan terjadinya kelelahan. Salah satu cara yang dapat dilakukan untuk mengurangi sikap membungkuk ketika bekerja adalah dengan menyediakan kursi yang dilengkapi oleh sandaran punggung bagi pekerja dengan posisi duduk. Pekerja dengan posisi berdiri dapat dilakukan dengan menyediakan meja yang memiliki ketinggian sesuai dengan tinggi pekerja sehingga jangkauan pekerja menjadi lebih dekat.

Dampak dari pencahayaan yang tidak memadai adalah terjadinya kelelahan mata, namun keadaan tersebut bersifat reversible. Maksudnya adalah apabila mata mengalami kelelahan, maka dengan melakukan istirahat cukup sepulang kerja maka pagi harinya mata akan pulih kembali (Departemen Kesehatan, 2007). Penerangan yang sesuai sangat penting untuk peningkatan kualitas dan produktivitas pekerja. Sebagai contoh, pekerjaan seperti menjahit membutuhkan tingkat penerangan lebih tinggi. 
Penerangan yang kurang sesuai akan menyebabkan pekerja terpaksa membungkuk dan mencoba memfokuskan penglihatan mereka, sehingga tidak nyaman dan dapat menyebabkan masalah pada punggung dan mata pada jangka panjang dan dapat memperlambat pekerjaan mereka (ILO, 2013).

Hasil observasi dan wawancara mengenai persepsi suhu di lingkungan kerja menyatakan bahwa sebagian besar pekerja merasa nyaman pada saat bekerja. Asumsinya semakin tidak nyaman suhu di lingkungan kerja makan akan semakin besar peluang terjadinya kelelahan. Kondisi lingkungan kerja yang panas akan menyebabkan rasa letih dan kantuk, selain itu mengalami kelelahan panas atau heat exhaustion dapat mengurangi kestabilan dan meningkatkan jumlah angka kesalahan kerja. Hasil penelitian menunjukkan bahwa sebagian besar pekerja merasa nyaman terhadap kondisi lingkungan kerja, dan yang lainnya menyatakan kurang nyaman terhadap kondisi lingkungan kerja. Sebagian besar pekerja yang merasa tidak nyaman bekerja menceritakan keluhan yang berkaitan dengan ketidaknyamanan adalah dikarenakan kebisingan yang ditimbulkan dari mesin jahit.

Asumsi peneliti bahwa dalam penelitian ini responden yang mengalami kelelahan dikarenakan sikap kerja yang tidak ergonomis, stasiun kerja, serta karakteristik individu. Pekerja di industri konveksi X sebagian besar mengalami kelelahan subjektif yang menandakan adanya perlemahan fisik dan adanya perlemahan kegiatan. Sedangkan pada kelelahan yang menandakan adanya perlemahan motivasi, pekerja jarang yang mengalami. Kelelahan yang menandakan adanya perlemahan fisik, responden paling sering mengalami keluhan nyeri di bagian punggung dan kaku di bahu. Keadaan tersebut disebabkan oleh pekerja bekerja pada sikap membungkuk, leher menekuk, dan banyak gerakan menggunakan tangan. Kursi yang tidak memiliki sandaran punggung juga penyebab dari pekerja yang membungkuk sehingga kursi dirasa tidak nyaman. Kelelahan yang menandai adanya perlemahan kegiatan yang dialami pekerja adalah mengantuk dan merasa ada beban pada mata, keadaan tersebut disebabkan karena pekerjaan dilakukan bersifat monoton yang melakukan kegiatan berulang.

Pekerja di industri konveksi $\mathrm{X}$ sebagian besar mengalami kelelahan subjektif yang menandakan adanya perlemahan fisik dan adanya perlemahan kegiatan. Sedangkan pada kelelahan yang menandakan adanya perlemahan motivasi, pekerja jarang yang mengalami. Kelelahan yang menandakan adanya perlemahan fisik, responden paling sering mengalami keluhan nyeri di bagian punggung dan kaku di bahu. Keadaan tersebut disebabkan oleh pekerja bekerja pada sikap membungkuk, leher menekuk, dan banyak gerakan menggunakan tangan. Kursi yang tidak memiliki sandaran punggung juga penyebab dari pekerja yang membungkuk sehingga kursi dirasa tidak nyaman. Kelelahan yang menandai adanya perlemahan kegiatan yang dialami pekerja adalah mengantuk dan merasa ada beban pada mata, keadaan tersebut disebabkan karena pekerjaan dilakukan bersifat monoton yang melakukan kegiatan berulang.

\section{SIMPULAN}

Hasil penelitian menunjukkan bahwa pekerja yang berjenis kelamin perempuan mengalami kelelahan tingkat tinggi, selain itu pekerja yang memiliki usia dan masa kerja yang lebih lama mengalami kelelahan kerja tinggi. Pekerja yang memiliki risiko sikap kerja tinggi mengalami tingkat kelelahan yang semakin tinggi. Sebagian besar pekerja mengalami kelelahan dikarenakan penggunaan stasiun kerja yang tidak ergonomis.

\section{DAFTAR PUSTAKA}

Departemen Kesehatan, RI., 2007. Jenis-Jenis Kelelahan Kerja dan Dampaknya terhadap Kesehatan. Jakarta: Departemen Kesehatan RI

Fitrihana, N., 2008, Perbaikan Area Kerja di Industri Garmen dengan Pendekatan Ergonomi Partisipatori dan Hubungan Dengan Produktivitas dan Kualitas. Tesis. Yogyakarta: Fakultas Teknik Univeristas Gajah Mada

Halim, I., Omar, A.R., 2011. A review on Health Effects Associated with Prolonged Standing in the Industrial Workplaces. IJRRAS [e-Journal] 8(1): pp. 14-21

Internasional Labour Organization (ILO)., 2013. Keselamatan dan Kesehatan Kerja di Tempat Kerja: Sarana Produktivitas. Jakarta: ILO

Kaergaard, A., Andersen, J.H., 2000. Musculosceletal Disorders of The Neck and Shoulders in Female Sewing Machine Operators. Prevalence, Incidene, and Prognosis. Occupational Environment Medicine, [e-Journal] 57: pp. 528-534

Maurits., Lintje, S. K., 2010. Sekilas tentang Kelelahan Kerja. Yogyakarta: Amara Books

Nurmianto, E., 2004. Ergonomi Konsep Dasar dan Aplikasinya. Surabaya: Guna Widya

Notoatmodjo, S., 2002. Metodologi Penelitian Kesehatan. Jakarta: Rineka Cipta 
Oentoro, S., 2004. Kampanye Atasi Kelelahan Mental dan Fisik. Jakarta: UI Press

Peraturan Menteri Tenaga Kerja dan Transmigrasi Republik Indonesia PER-01/MEN/I/2007 tentang Pedoman Pemberian Penghargaan Keselamatan dan Kesehatan Kerja (K3). Jakarta: Departemen Tenaga Kerja dan Transmigrasi

Ramli, S., 2013. Smart Safety: Panduan Penerapan SMK3 yang Efektif. Jakarta: Dian Rakyat

Restuputri, D. P., Resti P. D. S., 2015. Analisis Kecelakaan Kerja dengan Menggunakan Metode Hazard and Operability Study (HAZOP). Jurnal Ilmiah Teknik Industri, [e-Jurnal] 14(1): pp. 2435

Setyawati, L., 2010. Selintas Tentang Kelelahan Kerja. Yogyakarta: Amara Books

Sinyo., 2015. Hubungan Keselamatan dan Kesehatan Kerja (K3) dengan Produktivitas Kerja Karyawan PT. New Union jaya di Samarinda. Jurnal Ilmu Pemerintahan, [e-Jurnal] 3(4): pp. 1952-1963

Suma'mur., 2009. Higiene Perusahaan dan Kesehatan Kerja (HIPERKES). Jakarta: Sagung Seto

Susetyo, J., Titin, I., Suyasning, H., 2008. Prevalensi
Keluhan Subyektif atau Kelelahan karena Sikap Kerja yang Tidak Ergonomis pada Pengrajin Perak. Jurnal Teknologi, [e-Jurnal] 1(2): pp. 141-149

Tarwaka., Bakrie, S., Sudiajeng, L., 2004. ERGONOMI: Untuk Keselamatan, Kesehatan Kerja, dan Produktivitas. Surakarta: UNIBA Press

Tarwaka., 2010. Ergonomi Industri. Surakarta: Harapan Press

Tarwaka., 2015. Ergonomi Industri Dasar-Dasar Pengetahuan Ergonomi untuk Keselamatan Kesehatan Kerja dan Produktivitas. Surakarta: Harapan Press

Tampubolon, L. J., 2015. Efektivitas Pengawasan Keselamatan dan Kesehatan Kerja oleh Dinas Sosial dan Tenaga Kerja Kabupaten Sidoarjo Sebagai upaya Mewujudkan Budaya K3. Jurnal Kebijakan dan Manajemen Publik, [e-Jurnal] 3 (3): pp. 34-43

Ulfa, M., 2013. Sikap Kerja yang Berhubungan dengan Keluhan Subyektif pada Penjahit di Jl. Patua Surabaya. Skripsi. Surabaya: Fakultas Kesehatan Masyarakat Universitas Airlangga 